\title{
DRAMATURGI PENYANDANG OLIGODAKTILI
}

\author{
Sulaeman \\ Program Studi Jurnalistik Islam \\ Fakultas Ushuluddin dan Dakwah Institut Agama Islam Negeri Ambon \\ Jl. DR. Tarmidzi Taher, Kebun Cengkeh, Batu Merah Atas, Ambon, Maluku, 97128. \\ Telp. (0911) 344816 Email: sulaeman@iainambon.ac.id
}

\begin{abstract}
The purpose of this research it is analyzing the management of the impression in the stage before it or the stage back displayed in the process of communication at the daily life of social interaction with the surrounding environment for people with oligodactyly in Kampung Ulutaue. This research uses the method interpretative subjective with the approach dramaturgy, involving fifteen informants with ten men and five women were chosen purposively.Researchers are digging experience social interaction informants was conducted using data collected through in-depth interviews and observation participatory with the data supporting based on perspective the act of social and dramaturgy. The results of the study explain people oligodactyly manage the impression upon a stage before or the stage behind with verbal communication and nonverbal displayed social interaction in the process of communication with fellow people oligodactyly, family, the community government agencies, and television treating them by creating inconveniences in exertion to survive, weaken psychology self, marginalisation, traumatic, and self-denial its environment from suffering experienced. The contribution of the study is giving insight about impression management on people with oligodactyly by using dramaturgy perspective.
\end{abstract}

Keywords: management impression, people with oligodactyly, dramaturgy perspective.

\begin{abstract}
Abstrak
Tujuan penelitian ini adalah menganalisis pengelolaan kesan di panggung depan maupun panggung belakang ditampilkan dalam proses komunikasi pada interaksi sosial kehidupan sehari-hari dengan lingkungan sekitarnya bagi penyandang oligodaktili di Kampung Ulutaue. Penelitian ini menggunakan metode interpretatif subjektif dengan pendekatan dramaturgi, melibatkan lima belas informan dengan sepuluh laki-laki dan lima perempuan dipilih secara purposif. Peneliti menggali pengalaman interaksi sosial informan, dilakukan dengan menggunakan pengumpulan data melalui wawancara mendalam dan pengamatan partisipatif dengan data penunjang berdasarkan perspektif tindakan sosial dan dramaturgi. Hasil penelitian menjelaskan penyandang oligodaktili mengelola kesan pada panggung depan maupun panggung belakang dengan komunikasi verbal dan nonverbal ditampilkan interaksi sosial dalam proses komunikasi bersama dengan sesama penyandang oligodaktili, keluarga, masyarakat lembaga pemerintah, dan media televisi memperlakukan mereka dengan menciptakan ketidaknyamanan dalam beraktivitas untuk bertahan hidup, melemahkan psikologi diri, marginalisasi, traumatis, dan penyangkalan diri lingkungannya dari penderitaan dialami. Kontribusi penelitian ini adalah memberikan wawasan mengenai pengelolaan kesan penyandang oligodaktili menggunakan perspektif dramatugi.
\end{abstract}

Kata kunci : Penyandang oligodaktili, pengelolaan kesan, perspektif dramaturgi.

\section{Pendahuluan}

Pada Undang-Undang Nomor 4 tahun 1997 mengatur mengenai penyandang cacat yang mencakup pada penyadang cacat fisik, penyandang cacat mental, dan penyandang cacat fisik dan mental. Kemudian diperjelas lagi dalam Peraturan Pemerintah Nomor 36 tahun 1980, termasuk penyandang oligodaktili, diistilahkan "hipodaktili" adalah "jari tangan dan kaki yang kurang dari normal" (Hartanto, 2002: 1056). Oligodaktili kebalikan dari "polidaktili" berarti jemari tangan atau kaki yang lebih dari normal. Oligodaktili, tidak adanya satu dari jemari tangan dan kaki dan atau memiliki jemari tangan dan kaki yang tidak tidak normal. 
Komunitas oligodaktili yang tinggal di Kampung Ulutaue pada saat penelitian dilakukan, kampung ini dikaitkan dengan kampung dihuni oleh orang-orang "LobsterClaw Syndrome," meskipun banyak orangorang normal tinggal di sekitar lingkungan kampung tersebut. Kampung Ulutaue dikonstruksi media televisi sebagai "kampung manusia kepiting," menyebabkan beberapa masyarakat di kampung melakukan perlawanan, termasuk beberapa penyandang oligodaktili. Di antara mereka menyadari bahwa media televisi mengkonstruksi kampung semata-mata berorientasi pada keuntungan tanpa melihat fisik, psikologi, dan kondisi ekonomi penyandang oligodaktili.

Bagi penyandang oligodaktili, konstruksi media televisi dianggap perlakuan diskriminatif sebagai gambaran dari "stigma berhubungan dengan stereotip suatu penduduk yang diberikan sebagai penjulukan" (Goffman,1973: 14). Stigma, ciri negatif menempel pada pribadi mereka yang memiliki kelainan fisik berbeda dengan individu lainnya di lingkungan sekitarnya. Kelainan

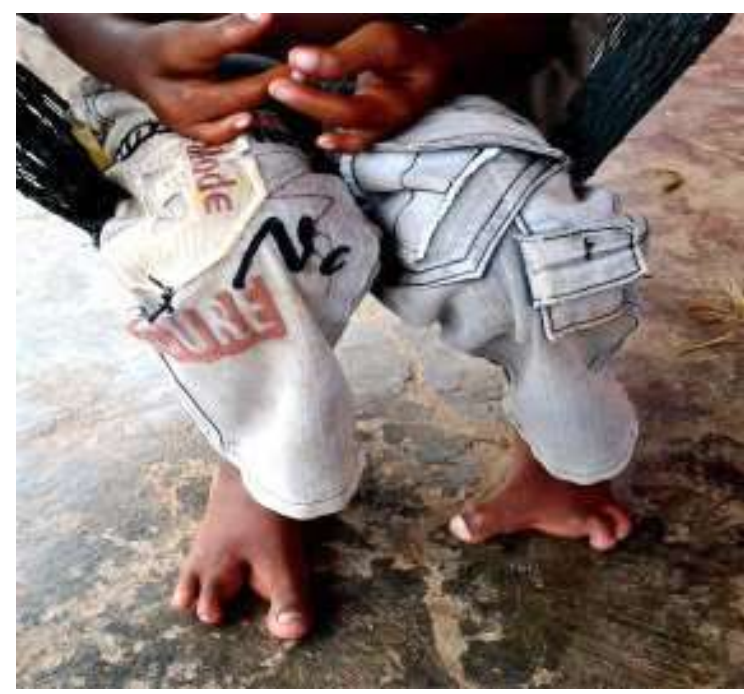

Gambar.1

Jemari tangan dan jemari kaki penyandang oligodaktili Sumber : Data Peneliti (2017) fisik dialami sebagai simbol identitas diri penyandang oligodaktili dalam kehidupan sehari-harinya telah membentuk dunia sosial diyakininya dan berkembang menjadi realitas dalam kehidupan sosial dengan julukan “jemari bertangkai dan atau atau keluarga bertangan kepiting yang serem, merinding, ibah, menakutkan, dan menjijikkan" bagi orang yang melihatnya. Reaksi verbal dan nonverbal yang muncul di lingkungan sekitarnya dengan mengejek, menghina, membuang muka, dan menghindar akan menimbulkan perasaan malu, rendah diri, kecenderungan menghindari, depresi, bunuh diri, memukul kepala dengan kayu, dan tidak menerima diri memiliki kelainan fisik yang dapat melemahkan diri para penyandang oligodaktili.

Penelitian ini bertujuan menganalisis pengelolaan kesan di panggung depan maupun panggung belakang ditampilkan dalam proses komunikasi pada interaksi sosial kehidupan sehari-hari dengan lingkungan sekitarnya bagi penyandang oligodaktili di Kampung Ulutaue

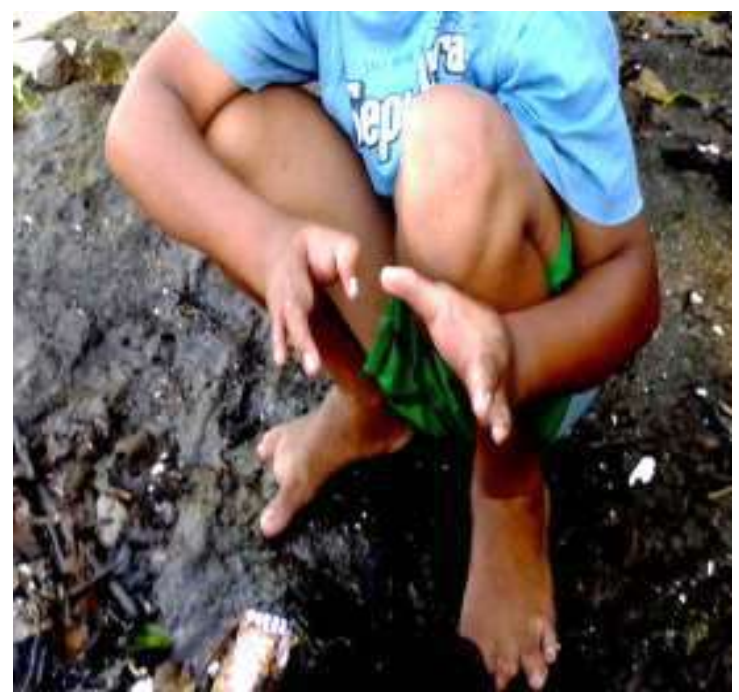

Gambar.2

Jemari tangan dan jemari kaki penyandang oligodaktili Sumber : Data Peneliti (2017) 


\section{Metode Penelitian}

Penelitian ini melibatkaan limabelas informan meliputi sepuluh laki-laki dan selebihnya perempuan. Usia mereka berkisar sepuluh hingga tujuhpuluh tiga tahun pada saat peneliti melakukan penelitian. Sepuluh subjek belum menikah, lainnya sudah menikah. Empat belas subjek memiliki pekerjaan sebagai wiraswasta, terutama pemulung laut (udang kecil, tiram kecil, dan kerang) dan satu subyek menganggur. Sebagian besar subyek tidak pernah sekolah, mereka tidak mampu berhitung, membaca dan menulis. Subyek sebagian besar memiliki tiga jemari tangan dan atau kaki. Selebihnya memiliki dua dan atau empat jemari tangan dan kaki. Jemari tangan dan kaki mereka sangat berbeda dengan jemari tangan dan kaki orang normal.

Teknik pengumpulan data dalam penelitian ini adalah dengan melakukan wawancara mendalam. Awalnya wawancara tidak mudah dilakukan, mereka menganggap peneliti sebagai jurnalis yang akan memperoleh keuntungan dari mereka mengenai pengalaman hidupnya kepada pembaca. Saat mereka bersedia diwawancarai, awalnya mereka tampak gelisah. Peneliti mampu mengumpulkan data dari subjek dengan cara, seperti peneliti menunjukkan kesabaran dan empati terhadap mereka. Hasil wawacara dimudahkan dengan peneliti menggunakan bahasa lokal (bahasa bugis) mereka. Akhirnya wawancara dilakukan dengan lancar dan intim. Wawancara berlangsung di rumah, pantai, sekolah, pasar dan di pesisir pantai.

Peneliti melakukan pengamatan di saat melakukan wawancara dan subjek melakukan aktivitas. Peneliti mengamati rumah mereka, tindakan verbal dan nonverbal, tempat di mana bekerja, termasuk pasar di mana mereka menjual hasil tangkapannya, lokasi mereka bermain dan atau menghibur diri mereka sendiri.

Penelitian ini menggunakan dua perspektif sebagai landasan teoretis, perspektif objektif dan subjektif.Perspektifobjektifuntuk meneliti penyandang oligodaktili didasari asumsi bahwa ada keteraturan dalam realitas sosial dan kehidupan sosial berhubungan dengan kelainan bentuk organ fisik untuk memprediksi hubungan sebab-akibat dan korelasi antara variabel, seperti menggunakan hipotesis. Dianalisis menggunakan data statistik untuk melihat apakah hipotesis diajukan dapat diterima dan atau tidak. Metode penelitian ini ternyata memberikan pengetahuan terbatas, kurang humanistik dan tidak akurat. Hasil penelitian tersebut, misalnya Gibson dan Zhong (2005), Lee (2008), Primack et al. (2009), and Brown and De Matviuk (2010). Di Indonesia, jenis penelitian ini meliputi penelitian dari Iba (2005) meneliti "Hubungan antara komunikasi dari paramedis dengan sikap pasien rawat inap mengenai layanan perawatan medis di rumah sakit umum daerah provinsi Sulawesi Tenggara," Dida (2011) meneliti "Pengaruh optimalisasi komunikasi kesehatan pada pusat pelayanan kesehatan dasar terhadap peningkatan derajat kesehatan anak usia dini di Jawa Barat," dan Agustini (2012) meneliti "Pengaruh komunikasi pemasaran jasa terhadap pencitraan pasien mengenai rumah sakit bersalin Emma Poeradiredja di Bandung."

Penelitian kuantitatif-statistik berbeda dengan penelitian perspektif subjektif bersifat 
“kualitatif” (Creswell, 1998: 15). Peneliti menggunakan perspektif “interpretatif” (Denzin dan Lincoln, 2005: 150-151) untuk mengeksplorasi individu dengan interpretasi penyandang oligodaktili dan interaksi sosial mereka dengan orang-orang di lingkungan sekitarnya atau lebih khusus, perspektif tindakan sosial dan dramaturgi, keduanya sebagai pelengkap satu sama lainnya. Kedua perspektif teori ini menjelaskan bahwa individu melakukan interaksi sosial dalam proses komunikasi di lingkungan sekitarnya dengan tampilan pengelolaan kesan pada panggung depan maupun belakang dalam menentukan tujuan mereka sendiri dalam hidupnya. Konteks realitas ini dianggap sebagai intersubjektif, berbagi, dan bernegosiasi. Cukup interaksi sosial dalam proses komunikasi dengan aktor komunikasi menyesuaikan tindakan mereka sendiri untuk penyesuaian diri dengan tindakan orang lain.

Penggunaan perspektif Max Weber (18641920), tindakan sosial berhubungan langsung dengan tindakan manusia. Penggunaan perspektif tindakan sosial, tindakan ini digerakkan oleh tampilan diri penyandang oligodaktili sebagaimana di ungkapkan oleh Erving Goffman (1922-1983) bahwa "ketika manusia berinteraksi dengan sesamanya, ingin mengelola kesan yang diharapkan tumbuh pada orang lain terhadapnya. Setiap individu melakukan pertunjukkan bagi orang lain." Asumsi teori ini, menjelaskan bagaimana penyandang oligodaktili mengelola kesan pada panggung depan maupun panggung belakang di lingkungan sekitarnya.

Aspek perspektif interpretatif, individu sebagai penyandang oligodaktili dapat mem- berikan tampilan diri tertentu mengenai kelainan fisik dialami dan mereka berinteraksi sosial dengan orang lain. Perspektif interpretatif dianggap sesuai dan lebih holistik untuk meneliti keunikan interaksi sosial penyandang oligodaktil dengan lingkungan sekitarnya. Dengan kata lain, tidak dilihat dari aspek kelainan fisik dialami, namum pengelolaan kesan dalam proses komunikasi mereka memiliki kelainan fisik secara subjektif. Penyandang oligodaktili bagi peneliti dianggap sebagai kelainan fisik, bukan sebagai penyakit. Kleinman et al. (1978) mendefinisikan bahwa penyakit sebagai "kerusakan organik dan proses patologis ditandai dengan gejala yang biasanya dapat diamati dan dinilai secara kuantitatif," sakit adalah "pengalaman penyakit atau sakit pasien" (Scharf and Vanderford, 2003: 9-34).

Hasil penelitian di Indonesia mengenai komunikasi berdasarkan teori dramatugis meliputi Arrianie (2006) meneliti kekerasan dalamkomunikasipolitikdidewanperwakilan rakyat Republik Indonesia; Bahfiarti (2011) meneliti komunikasi antarpribadi mantan narapida perempuan dalam adaptasi diri dan pengembangan hubungan pada masyarakat Bugis-Makassar di Kota Makassar; Rohim (2011) meneliti konstruksi diri dan perilaku komunikasi gelandangan di Kota Jakarta; Sulaeman (2014) meneliti konstruksi makna dan perilaku komunikasi penyandang oligodaktili di Kabupaten Bone, dan Sulastri (2015) meneliti komunikasi dakwah di Kota Padang.

Berdasarkan perspektif interpretif, penyandang oligodaktili memiliki pengelolaan kesan diasumsikan sebagai realitas subjektif. Dalam konteks ini, interaksi 
sosial dapat dihubungkan tampilan diri memiliki kelainan fisik, kepribadian diri, kepercayaan, dan nilai-nilai sosial-budaya. Ini menarik diteliti untuk mengetahui bagaimana subjek penelitian adalah penyandang oligokdatili mengelola kesan pada panggung depan maupun panggung belakang dengan komunikasi verbal dan nonverbal ditampilkan melakukan interaksi sosial dalam proses komunikasi dengan lingkungan di sekitarnya.

\section{Hasil Penelitian dan Pembahasan}

Merujuk analogi dramaturgi pandangan Erving Goffman berdasarkan kategori pengelolaan kesan pada panggung depan maupun panggung belakang dengan komunikasi verbal dan nonverbal yang ditampilkan proses komunikasi penyandang oligodaktili dalam interaksi sosial di lingkungannya dialami dalam kehidupan sehari-harinya telah membentuk dunia sosial diyakininya dan berkembang menjadi realitas dalam kehidupan sosial dengan temuan hasil penelitian menarik menjadi lima pengelolaan kesan ditampilan dengan sesama penyandang oligodaktili, keluarga, masyarakat, lembaga pemerintah, dan media televisi.

Interaksi sosial ditampilkan dalam proses komunikasi bersama sesama penyandang oligodaktili, seperti saudara kandung, paman, dan tante memiliki beberapa keunikan tersendiri. Keunikan pengelolaan kesan dengan menampilkan proses komunikasi dalam interaksi sosial, seperti intensitas komunikasi, perhatian dan dukungan satu sama lainnya, dan penekanan psikologi diri.

Proses komunikasi dengan sesama penyandang oligodaktili memiliki intensitas kurang baik dari segi frekuensi maupun kualitas ditampilkan di panggung depan "marah," kadangkala mereka merasa terhina dengan "melempar dan memecahkan" barang-barang kecil, seperti gelas dan piring. Pesan komunikasi nonverbal tidak menyenangkan, seperti "enak saja tinggal di rumah, makan, dan tidur bersama anak istri, tidak tau diri, makanya kerja, ... jangan menyusahkan orang lain di rumah" (Renita). Pesan tersebut akan menyakitkan diri bagi saudara kandung sesama penyandang oligodaktili dengan menampilkan panggung belakang "diam" dilakukan oleh saudara kandung.

Hubungan sosial sesama penyandang oligodaktili dalam tindakan interpersonal tanpa perhatian dan dukungan satu sama lainnya dengan pengelolaan kesan saling "mengacuhkan." Interaksi sosial dilakukan tidak memiliki relasi emosional, walaupun mereka memiliki ikatan hubungan sebagai keluarga kerabat. Sesama penyandang oligodaktili tidak memiliki kompetensi kedekatan, mereka tidak mampu mengelola peran diri yang seharusnya dan memunculkan "pembiaran" tampilan diri dipanggung depan. Peristiwa komunikasi ini dapat terjadi karena kualitas hubungan sosial interpersonal mereka yang kosong, tanpa saling perhatian dan dukungan satu sama lainnya dengan tampilan panggung belakang membuat dirinya "tekun belajar" untuk "menghibur" dirinya memiliki kelainan fisik.

Proses komunikasi terjadi sesama penyandang oligodaktili, memandang dirinya mendapatkan penekanan psikologi dan fisik sebagai komunikasi otoriter. Pola interaksi sosial penekanan dialami menyebabkan 
pesan komunikasi berlangsung dengan menampilkan pengelolaan kesan panggung depan "ancaman," seperti "saya sering dimarahi dan dipukul, ... saya tidak peduli dan mendengar apa yang bilang oleh tante" (Subaco), pola interaksi sosial seperti ini akan melemahkan dirinya lebih tertekan, menyesali diri terus-menerus, tidak memiliki harapan (ketidakpastian) masa depan, dan gairah hidup tidak ada untuk bekerja. Penggunaan pengelolaan kesan komunikasi otoriter, membuat mereka menampilkan panggung belakang "menghibur" diri dengan menyendiri, termenung, menangis, dan tidak memiliki harapan hidup ke depan, dan gairah hidup tidak ada untuk bekerja guna memperbaiki kehidupannya di masa akan datang.

Tindakan dari sebuah proses komunikasi mengandung unsur interaksi sosial dan menjadi tindakan komunikasi tersendiri bagi penyandang oligodaktili dengan keluarga inti dan keluarga kerabat dalam pengelolaan kesan pada panggung depan maupun panggung belakang akan menimbulkan, memperbesar, dan meneguhkan perasaan untuk berupaya menjadikan diri memiliki kondisi kelainan fisik, agar tetap menjalani aktivitas kehidupan sehari-hari dengan tampilan, seperti pengingkaran anak kandung, ditinggal pergi, perasaan iri hati, dan perbedaan kondisi fisik.

Panggung depan "penyangkalan" diri diterima penyandang oligodaktili dari keluarga, membuat diperlakukan tidak manusiawi. Penyangkalan keluarga merupakan diskriminasi keturunan melalui pesan komunikasi verbal "pengusiran keluarga" dan nonverbal "bukan keluarga," memicu diri mereka bertindak menyendiri dengan ekspresi wajah sedih, marah, dan menangis. Ekspresi wajah tersebut diibaratkan seperti sebuah buku dapat dibaca setiap keluarga dalam melakukan interaksi sosial.

Wajah sudah lama menjadi sumber informasi dalam komunikasi interpersonal. Inilah alat yang sangat penting dalam menyampaikan makna. Dalam beberapa detik ungkapan wajah dapat menggerakkan kita ke puncak keputusan. Kita menelaah wajah rekan dan sahabat kita untuk perubahan-perubahan halus dan nuansa makna dan mereka pada gilirannya, menelaah kita (Rakhmat, 1989:98).

Tindakan interaksi sosial keluarga memunculkan tindakan melemahkan diri penyandang oligodaktili dengan menampilkan diri panggung belakang "bermain" pada pesan komunikasi verbal "pergi ke pesisir pantai, pemulung laut, dan pergi ke rumah keluarga lainnya" dan nonverbal "bercanda" dengan anak-anak yang dimaknai untuk menghibur diri sendiri.

Interaksi sosial dengan ditinggal pergi orang tua tanpa ketahuan tempat tinggalnya, karena kelainan fisik dialami merupakan "pengabaian" diri diterima penyandang oligodaktili dirasakan tidak diterima keluarga sebagai pesan komunikasi nonverbal "keluarga pergi." Tindakan interaksi sosial keluarga memunculkan tampilan diripanggungbelakang "hiburan" melalui pesan komunikasi nonverbal "tindakan diam, memendang perasaan, dan beraktivitas" untuk menenangkan pikiran galau dialami penyandang oligodaktili.

Penolakan interaksi sosial dengan perasaan iri hati keluarga memunculkan "pembedaan" tampilan pengelolaan kesan pada panggung depan dengan pesan komunikasi nonverbal "tidak senang" diper- 
lihatkan keluarga pada diri penyandang oligodaktili menjalani kehidupan memiliki kelainan fisik. Perlakuan diterima dengan menampilkan diri "pikiran positif" sebagai pesan komunikasi verbal dalam pengelolaan kesan panggung belakang untuk penguatan keimanan dalam menjalani kehidupan, tampilan diri yang diperlihatkan dalam menjalani kehidupan sudah ditakdirkan oleh Allah SWT.

Interaksi sosial kakek - nenek, dan saudara kandung dari keluarga inti dari bapak dengan anak penyandang oligodaktili yang telah terlahir memiliki kelainan fisik yang telah di tinggal mati ibunya, serta bapak telah menjadi duda menikah lagi dengan wanita lain dan "menelantarkan" anak kandungnya sendiri, karena perbedaan fisik dialami merupakan pengelolaan kesan pada panggung depan penerimaan pada anak penyandang oligodaktili. Perlakuan ini diterima dengan menampilan diri panggung belakang "tinggal bersama keluarga," orang tua tidak pernah lagi kembali melihat anaknya di kampung dan seperti apa anaknya sekarang.

Penyandang oligodaktili membangun interaksi sosial dalam proses komunikasi bersama dengan masyarakat seperti tetangga, penjual sayuran, pemilik usaha toko, perkebunan, pemilik usaha bagan nelayan, sopir, penumpang angkutan, dan anak-anak di kampung dengan pengelolaan kesan pada panggung depan dan panggung belakang seperti julukan diri, peristiwa komunikasi, pengusiran, dan diskriminasi.

Pengelolaan kesan melalui panggung depan "cemohan" diri diterima penyandang oligodaktili dari masyarakat, mencerminkan stigmatisasi penjulukan "jemari bertangkai" melalui pesan komunikasi verbal "tertawa" melihat tampilan diri penyandang oligondaktili memiliki kelainan fisik, termasuk kategori "public stigma," penilaian masyarakat terhadap kelompok tertentu, di mana penilaian berdasarkan sosial budaya yang dianut (Corrigan dan Watson, 2002: 7). Dalam konteks interaksi sosial, tindakan ditampilkan masyarakat adalah cemohan melalui pesan komunikasi verbal dengan tertawa yang diterima penyandang oligodaktili, mencerminkan stigmatisasi sebagai tindakan penjulukan. Tindakan tersebut memunculkan tampilan diri panggung belakang "ingin membunuh diri" melalui pesan komunikasi nonverbal "memukul diri" memicu penyandang oligodaktili "pengisolasian diri" ditandai perasaan emosional merefleksikan cemohan akan kondisi kelainan fisik dialami untuk menghindari interaksi sosial pada lingkungan.

Bagi penyandang oligodaktili peristiwa komunikasi terjadi di pasar, seperti interaksi sosial dengan penjual sayuran yang dianggap bahwa kelainan fisik dialami dirinya menjadi penyebab munculnya proses komunikasi tampilan panggung depan "penghinaan" dilakukan penjual sayuran yang diterima penyandang oligodaktili dengan pesan komunikasi verbal "kepribadiaan dan kemampuan" diri berdampak melemahkan. Tindakan diterima dengan pengelolaan kesan "minta maaf" melalui tampilan diri pesan komunikasi verbal sebagai panggung belakang dalam melindungi "harga diri," guna memperoleh perasaan hormat dan kemulian dari masyarakat. Ungkapan ini senada dikemukakan oleh Argyle (1994: 89) 
bahwa "pengelolaan kesan memiliki motivasi primer untuk mempertahankan dan atau meningkatkan harga diri ...." Para penyandang oligodaktili melakukan pengelolaan kesan pada panggung belakang dengan tampilan diri didasarkan motivasi untuk mempertahankan "kepribadiaan dan kemampuan diri" dalam melindungi "harga diri" memiliki kelainan fisik.

Relasi sosial dengan masyarakat memunculkan "pelecehan" diri diterima penyandang oligodaktili melalui pengelolaan kesan panggung depan, dianggap sebagai pengusiran disebabkan dari kelainan fisik dialami, "Malu rasanya, air mati mau jatuh, di usir punya toko" (Ulhadi). Tindakan pelecehan merupakan pesan komunikasi verbal "penghinaan" dikelola dengan kesan pada panggung belakang "sabar" melalui komunikasi nonverbal "diam dan memendang perasaan."

Tindakan diskriminasi sosial pada masyarakat dipicu kelainan fisik di alami penyandang oligodaktili, seperti " $D i$ ledekin, yaa tidak apa-apa, nanti temanteman berhenti meledek" (Subaco) dengan tampilan panggung depan "pengucilan" diri diterima dengan pesan komunikasi nonverbal "menjauhi diri," seperti dijelaskan Goffman (1963: 3) sifat interaksi dan komunikasi tergantung pada "discredit stigma" aktor menganggap perbedaan telah diketahui oleh anggota penonton atau jelas bagi mereka (seperti, orang yang tubuh bagian bawahnya lumpuh atau kehilangan anggota badan)." Untuk menetralisasi perlakuan ini, mereka mengelola kesan pada panggung belakang ditampilkan dalam bentuk diri "memaklumi” melalui pesan komunikasi nonverbal "tindakan diam, dan memendang perasaan" diri memiliki kelainan fisik sejak lahir.

Penyandang oligodaktili di Kampung Ulutaue, kurang lebih empatpuluh tahun menggeluti pekerjaan nelayan dan melakukan interaksi sosial dengan lembaga pemerintah, seperti Kepala Desa Mario dan Wusto Kecamatan Mare Kabupaten Bone, dinas-dinas kepemerintahan meliputi Dinas Perikanan dan Kelautan, Perindustrian dan Perdagangan, Kehutanan dan Pertanian, Dinas Kesehatan Kabupaten Bone sebagai lembaga penguatan pada diri.

Interaksi sosial dengan pemerintah merupakan proses komunikasi kepedulian mengunjungi penyandang oligodaktili, proses pembelajaran, perhatian program pemberdayaan, dan dukungan bantuan pemberdayaan. Tindakan proses komunikasi lembaga pemerintah, penyandang oligodaktili menampilkan pengelolaan kesan pada panggung depan "ketidakpercayaan" sebagai pesan komunikasi nonverbal "ketiadaan realisasi" bantuan pemberdayaan yang sudah diprogramkan pemerintah dalam bentuk "surat keputusan" dikeluarkan Kepala Dinas dan atau kepala bagian Pemerintahan di Kabupaten Bone. Penerimaan tindakan pengelolaan kesan "sabar menunggu" melalui tampilan diri pesan komunikasi nonverbal pada panggung belakang mengenai keterlibatan pemerintah dalam dukungan sosial, khususnya pemberdayaan dalam peningkatan kesejahteraan ekonomi nelayan masih dianggap kebijakan pemerintah belum berpihak kepada mereka. 
Tindakan media televisi melakukan peliputan terhadap penyandang oligodaktili, peliputannya tidak berhasil atau gagal, media televisi diusir supaya tidak melakukan peliputan. "Pengusiran" sebagai tampilan panggung depan penyandang oligodaktili, karena terganggunya psikologi diri dan sosial dari peliputan media televisi yang sebelumnya mengkonstruksi penyandang oligodaktilimelaluipesan komunikasiverbal, seperti "manusia jari kepiting, kampung manusia jari kepiting, dan fakta unik keluarga bertangan kepiting." Konstruksi media tersebut sebagai tampilan pengelolaan kesan "perasaan marah, trauma, dan emosional" panggung belakang ditampilkan pada diri penyandang oligodaktili dengan perasaan malu dan menghindar melakukan interaksi sosial dengan lingkungan di sekitarnya dan melemahkan diri mereka memiliki kelainan fisik untuk melakoni kehidupannya lebih baik.

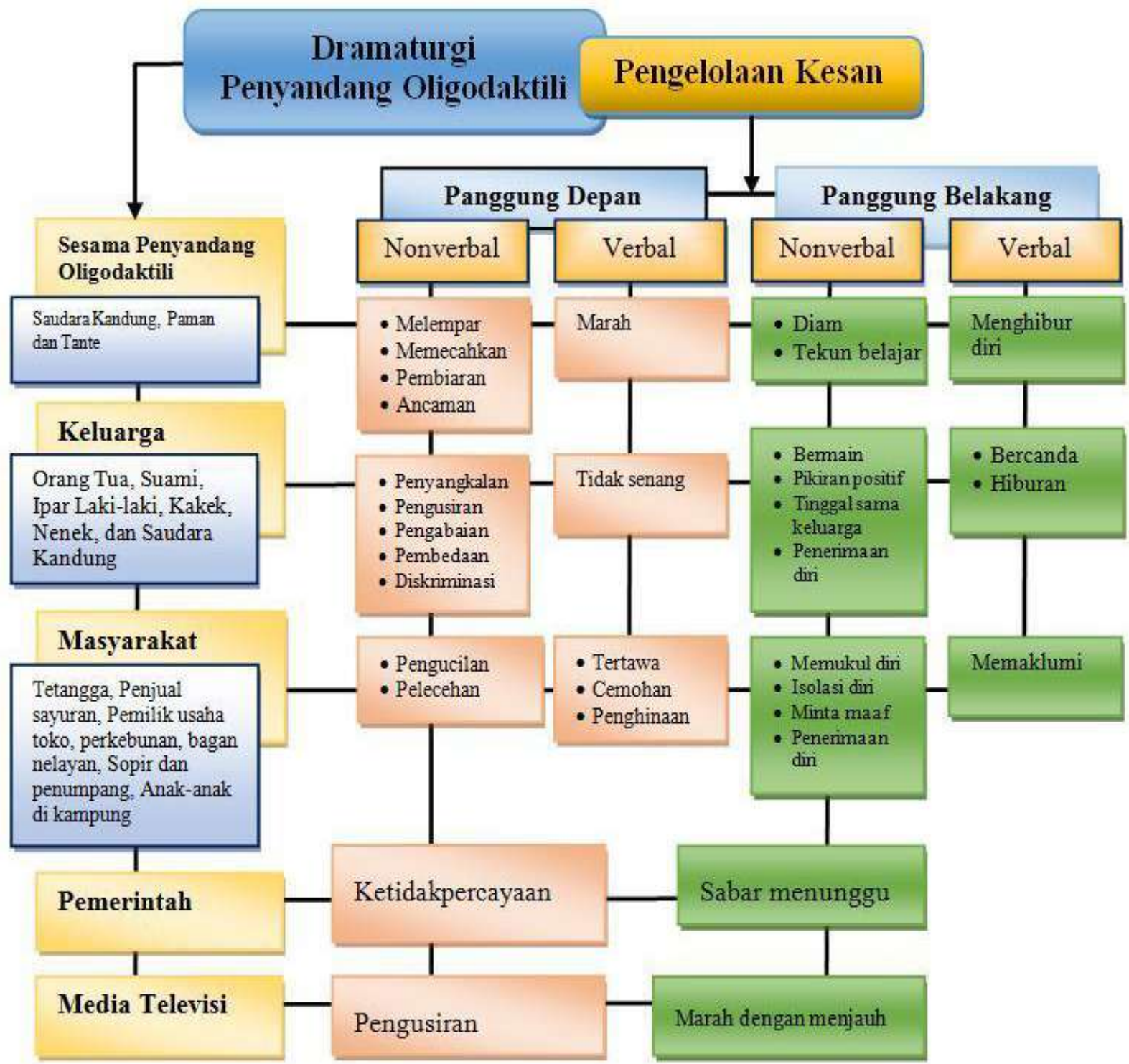

Gambar 3. Pengelolaan kesan penyandang oligodaktili dengan perspektif dramaturgi Sumber : Data Peneliti 2017 
Semua interaksi sosial dalam proses komunikasi diterima penyandang oligodaktili dari sesama penyandang oligodaktili, keluarga, lembaga pemerintah, masyarakat, maupun media televisi melalui panggung depan kemudian terejawantahkan dalam bentuk taktik-taktik yang diterapkan penyandang oligodaktili sebagai panggung belakang dengan diam, tekun belajar, bermain, hiburan, menanggapi pikiran positif, tinggal bersama keluarga dari pihak ibu, keinginan bunuh diri, minta maaf, penerimaan diri, memaklumi, sabar menunggu, dan marah dengan menjauhi. Akumulasi dari semua hal itulah yang kemudian memunculkan berbagai sikap dari para penyandang oligodaktili yang tentu saja adalah fenomena yang wajar dan dialami. Burke (1968:133) sudah menegaskan bahwa dasar dari suatu tindakan, berawal dari pemahaman terhadap suatu kondisi dan tentu saja motivasi kedepannya.

Interaksi dan komunikasi memiliki dimensi hubungan terdapat dalam karakter hubungan tidak sehat sebagaimana dijelaskan Rogers bahwa “... individu memiliki sikap negatif kecenderungannya memunculkan ketidakharmonisan menciptakan ketidakcocokan pemahaman dalam kehidupannya" (Littlejohn dan Foss, 2009: 310). Proses komunikasi melalui pengelolaan kesan hubungan sosial menunjukkan adanya ketidaknyamanan pada lingkungan. Ketidaknyamanan disebabkan, baik pesan verbal dan nonverbal maupun dampak psikologi diri bersifat melemahkan diri penyandang oligodaktili.

Penyandang oligodaktili mengelola kesan pada panggung depan maupun di panggung belakang, dari bahasa verbal dan nonverbal ditampilkan dalam proses komunikasi sebagai upaya dilakukan untuk "memupuk kesan" dengan tujuan tertentu membekas pada individu lain, seperti dijelaskan Mulyana (2010: 108-109) "peran dimaksudkan sebagai “ekspektasi didefinisikan secara sosial yang dimainkan individu dalam suatu situasi untuk memberikan citra tertentu kepada khalayak yang hadir." Keterkaitan dengan ini, penyandang oligodaktili menampilkan perannya tersebut dan ingin memberikan tampilan diri supaya diterima di lingkungan sekitarnya melalui cara yang ditampilkan supaya dapat menimbulkan kesan.

Pengelolaan kesan penyandang oligodaktili ditampilkan dalam proses komunikasi pada interaksi sosial di lingkungan memperlihatkan penolakan akan kondisi kelainan fisik dialami. Tindakan pada lingkungan diterima penyandang oligodaktili yang menurut Mead dianggap "diri pada dasarnya bersifat sosial." Bagi Goffman, individu tidak hanya sekedar mengambil peran orang lain, melainkan bergantung pada orang lain untuk melengkapi citra diri tersebut (Mulyana, 2006: 110). Penyandang oligodaktili dapat menampilkan diri dalam bentuk pengelolaan kesan saat berinteraksi dan berkomunikasi dengan lingkungan. Seperti juga pendapat Mulyana (2006: 112) bahwa pengelolaan kesan "digunakan untuk memupuk kesan-kesan tertentu dalam situasi tertentu untuk mencapai tujuan tertentu" sehingga tampilan diri akan kondisi kelainan fisik disajikan dapat diterima pada lingkungan. Konsep dikembangkan oleh Goffman menjadi rujukan yang baik untuk menggambarkan 
pengelolaan kesan ditampilkan, baik pesan komunikasi verbal maupun nonverbal yang terinspirasi oleh teori dramaturgi.

Para penyandang oligodaktili yang sudah memiliki pola pikir dan memiliki pengalaman tertentu, akan menerapkan beberapa taktik dalam pengelolaan kesannya sebagaimana ditunjukkan mereka pada keluarga dan masyarakat. Apapun itu, yang diperlihatkan tetap saja keinginan untuk berkamuflase dan menjaga posisi dirinya di mata keluarga dan masyarakat. Baik itu bermain, hiburan, menanggapi pikiran positif, minta maaf, sabar, ingin bunuh diri, dan memaklumi, semuanya adalah bentuk untuk mempertahankan posisi dan harga diri memiliki kelainan fisik. Seperti inilah yang terus dilakukan dan semuanya merupakan realitas yang muncul dari fenomena dialami sebelumnya. Kerangka pengalaman, interaksi sosial pada keluarga dan masyarakat, serta pengetahuan yang ada, menjadi faktor dasar dalam membentuk proses komunikasi mereka pada lingkungan keluarga dan masyarakat.

Proses komunikasi diterima penyandang oligodaktili akan kondisi kelainan fisik dialami sebagai penolakan tindakan komunikasi dari masyarakat, seperti penghinaan, pengucilan, dan pelecehan dianggap stigmatisasi berdasarkan tindakan diskriminasi terjadi karena adanya ketakutan pada lingkungan masyarakat, seperti kelainan fisik akan menular, penyakit diabetes akan menular, dan makanan menjijikkan dan takut di makan. Tindakan penjulukan diterima dalam penolakan dari masyarakat, seperti jari bertangkai dan atau manusia jari kepiting, aib untuk lingkungan di sekitarnya.
Stigmatisasi diterima akan kondisi kelainan fisik dialami dalam tindakan penjulukan dan diskriminasi akan melemahkan diri mereka yang merasakan diri tidak berharga, tidak berguna, tidak berdaya, menurunkan motivasi untuk menjalani kehidupan, dan menarik diri pada lingkungan untuk melakukan interaksi sosial. Stigmatisasi kondisi kelainan fisik dialami dan bagi Goffman melihat ada kesenjangan antara citra diri yang individu inginkan ketika melakukan interaksi dan komunikasi pada lingkungan, dengan stigma mereka miliki, sehingga setiap individu memiliki stigma, akan memiliki sifat interaksi dramaturgis berbeda, tergantung kepada jenis stigma dimilikinya (Kuswarno, 2009: 102).

Penyandang oligodaktili memaknai kelainan fisik secara simbolis tidak muncul dengan sendirinya dan ketika mereka melakukan interaksi sosial, mengelola kesan yang diharapkan tumbuh pada orang lain terhadap dirinya. Pandangan Goffman, tidak terlepas dari gagasan Cooley dalam (Mulyana, 2006: 73) dengan "the looking-glass self" menyatakan bahwa cara individu membangun peran dalam interaksi sosial bergantung dari pola persepsi. Pola persepsi itulah menentukan cara pandang yang digunakan penyandang oligodaktili dalam mereaksikan dirinya pada lingkungan di sekitarnya.

Mengartikulasikan interaksi sosial penyandang oligodaktili dengan teori tersebut dapat dipahami bahwa mereka melakukan interaksi sosial melalui proses komunikasi, tidak terlepas dari penilaian mereka terhadap sesama penyandang oligodaktili, keluarga, masyarakat, lembaga pemerintah, maupun media televisi dalam membawa realitas kelainan fisik kepada dirinya. 


\section{Simpulan}

Penyandang oligodaktili sebagai subjek penelitian telah mengelola kesan pada panggung depan bersama dengan sesama penyandang oligodaktili, keluarga, masyarakat lembaga pemerintah, dan media televisi memperlakukan dengan menciptakan ketidaknyamanan, penghinaan, pengucilan, pelecehan, penyangkalan, dan penjulukan merupakan stigmatisasi, karena adanya ketakutan seperti kelainan fisik akan menular, penyakit diabetes akan menular, dan makanan menjijikkan dan takut di makan.

Interaksi sosial dalam proses komunikasi diterima melalui panggung depan kemudian terejawantahkan dalam bentuk taktik-taktik yang diterapkannya sebagai panggung belakang dengan diam, tekun belajar, bermain, hiburan, menanggapi pikiran positif, tinggal bersama keluarga dari pihak ibu, keinginan bunuh diri, minta maaf, penerimaan diri, memaklumi, sabar menunggu, dan marah dengan menjauhi. Akumulasi dari semua ini dapat melemahkan psikologi diri dan sosial penyandang oligodaktili dari kelainan fisik dialami.

Penggunaan teori tindakan sosial dan dramaturgi telah bermanfaat dalam mengeksplorasi interaksi sosial dalam proses komunikasi tampilan diri penyandang oligodaktili sebagai upaya untuk memupuk kesan secara verbal dan nonverbal yang telah digunakan untuk menyesuaikan panggung depan mereka dan untuk meminimalisasi perasaan malu, rendah diri atau untuk menumbuhkan citra yang lebih baik di depan orang lain sebagai panggung belakang.
Penelitian ini telah membahas beberapa aspek interaksi sosial dalam proses komunikasi penyandang oligodaktili. Banyak aspek lain masih perlu dilakukan penelitian, salah satunya adalah bagaimana makna diri penyandang oligodaktili. Telah ditemukan, misalnya mereka berbeda bentuk organ fisik dengan orang lain, dan kelainan fisik dialami memiliki kekhasan sosial budaya dan anugerah dari Allah SWT. Tentu saja topik ini berada di luar diskusi kita saat ini.

\section{Daftar Pustaka}

Agustini, Prima M. (2012). Pengaruh Komunikasi Pemasaran Jasa Terhadap Pencitraan Pasien Mengenai Rumah Sakit Bersalin Emma Poeradiredja: Survei Eksplanatori mengenai Pengaruh Komunikasi Pemasaran Jasa terhadap Pencitraan Pasien Mengenai Rumah Sakit Bersalin Emma Poeradiredja Melalui Risiko, Kualitas Jasa, dan Posisi Jasa yang Diterima Pasien Periode Juni-September 2011 di Kota Bandung. Unpublished Doctoral Dissertation Padjadjaran University.

Argyle, Michael. (1994). The Psychology of Interpersonal Behaviour. USA: Penguin Books Limited.

Arrianie, Lely. (2006). Kekerasan dalam Komunikasi Politik (Studi Dramaturgis Tentang Peristiwa Kekerasan dalam Penyampaian Pesan-Pesan Politik di Dewan Perwakilan Rakyat Republik Indonesia). Unpublished Doctoral Dissertation Padjadjaran University.

Bahfiarti, Tuti. (2011). Komunikasi Antarpribadi Mantan Narapida Perempuan dalam Adaptasi Diri dan Pengembangan Hubungan pada Masyarakat Bugis-Makasar di Kota Makassar. Unpublished Doctoral Dissertation Padjadjaran University. 
Burke, Kenneth. (1968). Dramatism, in International Encyclopedia of the social Sciences. New York melalui <http:// uclinks.org/twiki/pub/SolanaBeach/ PdfWeek5/Overington_BurkeArticle.pdf. [04/15/2016].

Brown, William J. and Marcela AC De Matviuk. (2010). "Sports Celebrities and Public Health: Diego Maradona's Influence on Drug Use Prevention." Journal of Health Communication 16., h.726-749.

Corrigan, Patrick W and Amy C. Watson. (2002). The Impact of Stigma on Service Acces and Participation (A Guideline Developed For The Behavioral Health Recovery Management Project). University of Chicago Center For Psychiatric Rehabilitation. http://www.bhrm.Org/ guidelines/stigma.pdf.(06/24/2016).

Creswell, John W. (1998). Qualitative Inquiry and Research Design:Choosing Among Five Traditions. Thousand Oaks: CA. Sage Publication Inc.

Denzin, Norman K. Yvonna S. Lincoln. (2005). Handbook of Qualitative Research. London: Sage Publications.

Gibson, DeWan and Mei Zhong. (2005). "Intercultural Communication Competence in the Healthcare Context." International Journal of Intercultural Relations 29., h. 621-634

Goffman, Erving. (1959). The Presentation of Self Everyday Life. Harmondworth: Penguin.

Hartanto, Huriawati. (2002). Kamus Kedokteran Horland WA. Newman. Jakarta: EGC.

Iba, La. (2005). Hubungan antara Komunikasi dari Paramedis dengan Sikap Pasien Rawat Inap Mengenai Layanan Perawatan: Studi pada Layanan Perawatan Medis Rumah Sakit Umum Daerah Propinsi (RSUP) Sulawesi Tenggara. Unpublished Master's Thesis Padjadjaran University.
Kuswarno, Engkus. (2009). Metode Penelitian Komunikasi: Fenomenologi, Konsepsi, Pedoman, dan Contoh Penelitian. Bandung: Widya Padjadjaran.

Lee, Chul-Joo. (2008). "Does the Internet Displace Health Professionals?" Journal of Health Communication 13., h. 450-464.

Littlejohn, Stephen W., and KarenA. Foss. (2009). Theories of Human Communication. $8^{\text {th }} \mathrm{ed}$. Belmont California: Wadsworth Publishing Company.

Mulyana, Deddy. (2006). Metodologi Penelitian Kualitatif: Paradigma Baru Ilmu Komunikasi dan Ilmu Sosial Lainnya. Cet.V. Bandung: PT. Remaja Rosdakarya.

Peraturan Pemerintah Nomor 36 Tahun 1980 Tentang Usaha Kesejahteraan Sosial Penyandang Cacat.

Primack, Brian A., Jaime Sidani, May V. Carroll, and Michael J. Fine. 2009. "Associations Between Smoking and Media Literacy in College Students." Journal of Health Communication 14., h. 541-555.

Rakhmat, Jalaluddin. (1989). Psikologi Komunikasi. Bandung: Remaja Rosdakarya.

Rohim, Syaiful. (2011). Konstruksi Diri dan Perilaku Komunikasi Gelandangan di Kota Jakarta (Studi Fenomenologi Terhadap Julukan Gelandangan "Manusia Gerobak"). Unpublished Doctoral Dissertation Padjadjaran University.

Sulaeman, (2014). Konstruksi Makna dan Perilaku Komunikasi Penyandang Oligodaktili (Studi Fenomenologi Penyandang Oligodaktili di Kampung Ulutaue Kabupaten Bone). Unpublished Doctoral Dissertation Padjadjaran University.

Sulastri, Irta. (2015). Komunikasi Dakwah di Kota Padang (Kajian Fenomenologi Tentang Perilaku Komunikasi Dai dalam Berdakwah di Kota Padang). Unpublished Doctoral Dissertation Padjadjaran University.

Undang-Undang Nomor 4 Tahun 1997 Tentang Penyandang Cacat. 